\title{
Effects of Mifepristone and Tamoxifen on Calcium Modulation in DU-145 Prostate Cancer Cells
}

\author{
Yeo-Reum Kim and Byeong Gee Kim* \\ Department of Biological Sciences, Pusan National University, Busan 609-735, Korea
}

Received July 28, 2010 /Accepted August 14, 2010

\begin{abstract}
Mifepristone (MIF) and Tamoxifen (TAM) have been used in the treatment of prostate cancer and breast cancer for more than a decade. MIF can induce apoptosis in both AR-positive and -negative prostate cancer cells. Because of its pleiotropic ligand-receptor properties, TAM exerts cytotoxic activity in estrogen (ER)-positive and various ER-negative cancer cells. However, the molecular mechanisms of these two substances are not yet clear. In the present work, we report that the cytotoxic effects of MIF and TAM are due to the modulation of intracellular $\mathrm{Ca}^{2+}$ level in DU-145, androgen-insensitive cells. When the cells were treated with micromolar concentrations of either MIF or TAM, the growth and viability were significantly decreased in a dose- and time-dependent manner. The apoptosis induced by MIF or TAM was further proved and analyzed by confocal laser scanning microscopy (CLSM) and fluorescence-activated cell sorting (FACS). In the cells cultivated in a normal $1.5 \mathrm{mM} \mathrm{Ca}^{2+}$ medium, both MIF and TAM also induced an increase of the intracellular $\mathrm{Ca}^{2+}$ level in a dose-dependent fashion. Since a change in calcium level could not be found in cells of the $\mathrm{Ca}^{2+}$-free medium, the increase of intracellular $\mathrm{Ca}^{2+}$ level might be due to an increase in extracellular calcium uptake. Our results show that the apoptotic effect was more prominent in TAM treatment compared to MIF treatment in DU-145 cells. The above findings might be due to the difference in the uppermost pathways of apoptosis induced by either MIF or TAM. When we checked the level of procaspase- 8 activation, TAM showed minor level of activation, as opposed to MIF, which exerted strong activation. In both treatments, the levels of anti-apoptotic protein Bcl-2 decreased, and pro-apoptotic protein Bax level increased more than 2-fold. The activation of caspase-3, a key protease enzyme in the downstream pathway of apoptosis, was much higher in the cells treated with TAM, compared to the MIF treatment. The overall apoptotic activity shown in the present work was closely related to intracellular $\mathrm{Ca}^{2+}$ concentration levels. Therefore, the cytotoxic activity induced by MIF and TAM might have been due to intracellular calcium modulation.
\end{abstract}

Key words : Apoptosis, calcium level, mifepristone, prostate cancer, tamoxifen

\section{Introduction}

Prostate cancer is the most common cancer in men of the western world. In the USA, it is the second leading cause of cancer-related death in men. Recently, the number of cases diagnosed with prostate cancer is rapidly on the increase in Korea. Steroid hormones, especially androgens, play critical roles in the development and growth of the male reproductive system. Their functions are mediated by the androgen receptor (AR). MIF is a progesterone analogue and is known as a potent progesterone antagonist. MIF is also used as a selective androgen receptor (SAR) modulator because this compound interacts with AR and its corepressors $[2,19]$. Because of this strong AR antagonistic activity, MIF

\footnotetext{
*Corresponding author

Tel : +82-51-510-2286, Fax : +82-51-581-2962

E-mail : bgkim@pnu.edu
}

has been used in the treatment of prostate cancer. Although MIF has been known to inhibit prostate cancer cell growth in vitro and in vivo, its molecular mechanisms are not yet clear [2,6,20]. MIF can induce apoptosis in androgen-sensitive (LNCaP) and androgen-insensitive (PC-3, DU-145) cell lines [22]. These findings suggest that the apoptotic characteristics induced by MIF are not just androgen antagonistic activities. Even though the precise role of MIF in apoptosis appears to be complex and not clear, it has been known that mitochondria play key roles in the apoptotic process through the activation of caspases $[10,14,18]$.

TAM has been used in the treatment of breast cancer for more than three decades; however, the precise molecular mechanisms underlying TAM-induced cytotoxicity are as of yet unclear. Recent reports have shown that TAM inhibits the proliferation and induces apoptosis not only in estrogen receptor (ER)-positive breast cancer cells, but also in ER-neg- 
ative breast cancer cells and other cancer cells; i.e., prostate cancer, ovarian cancer, colorectal cancer, and brain cancer $[1,13,17]$. Non-genomic effects of TAM has been suggested in many cell lines; including the inhibition of protein kinase C [3], interferences with the function of ion channels [7], and the activation of extracellular signal-regulated kinase (ERK1/2) [23]. Recently, it has also been reported that TAM induces apoptosis by the initiation of a mitochondrial death program [8]. TAM-induced cytotoxicity has been associated with release of mitochondrial cytochrome $c$, a decrease of mitochondrial membrane potential, an increase in production of reactive oxygen species, and stimulation of mitochondrial NO synthase.

Apoptosis is physiological cell death regulated by genetic mechanisms and is principally characterized by morphological and biochemical changes in their nuclei, including chromatin condensation and internucleosomal DNA fragmentation. Caspases, a family of cysteine protease, play a central role in the signaling and execution of apoptosis [21]. The activation of caspase-3 during apoptosis is regulated by multiple pathways. One of the important pathways to activate caspase- 3 is mediated by the alteration of mitochondria. Mitochondrial depolarization and/or caspase-3 activation are known to be regulated by the cytosolic free calcium concentration in many cell systems [16]. Mitochondria are involved in multiple $\mathrm{Ca}^{2+}$ transport mechanisms. When the cell is overloaded with $\mathrm{Ca}^{2+}$, mitochondria take up cytosolic free $\mathrm{Ca}^{2+}$, inducing a change in the mitochondrial membrane potential. The collapse of the membrane potential results in the release of cytochrome $\mathrm{c}$ and other apoptosis-inducing factors from mitochondria, which is followed by the activation of caspase, nuclear fragmentation, and cell death.

In recent years, a great deal of attention has been placed on the possible correlation between the effects of members of the $\mathrm{Bcl}-2$ family of proteins on $\mathrm{Ca}^{2+}$ homeostasis and their role in the control of apoptosis [5]. Bcl-2 is the first family member proposed to have the ability to alter intracellular $\mathrm{Ca}^{2+}$ homeostasis. Anti-apoptotic members in the Bcl-2 family, such as Bcl-2 and Bcl-XL, are preferentially localized in the mitochondrial membrane and protect mitochondria from perturbation, thereby preventing cell death [9]. The specific localization of Bcl-2 in the membranes of mitochondria and $\mathrm{ER}$, and the demonstration that Bcl-2 acts as an ion channel when inserted into lipid bilayers suggest that $\mathrm{Ca}^{2+}$ signaling could be a target of the action of this anti-apoptotic oncopro- tein [15]. Therefore, in the present work, the effects of MIF and TAM on intracellular calcium level change, cell viability, and Bcl-2 family protein expressions were investigated to see if intracellular calcium modulation leads to apoptotic death in DU-145 human prostate cancer cells.

\section{Materials and Methods}

\section{Chemicals and cell culture}

([Z]-4-[1-(p-[Dimethylaminoethoxy] phenyl)-2-phenyl-1butenyl] phenol) (TAM), 3-[4,5-dimethylthiazol-2-yl]-2,5-diphenyl tetrazolium (MTT), Fluo-3/AM, Pluronic F-127, propidium iodide (PI), Hoechst 33342, ribonuclease A, dimethylsulfoxide (DMSO), Dulbecco's modified Eagle's medium (DMEM, with L-glutamine and 1,000 mg/l Glucose) were purchased from Sigma Chemical Co (St. Louis, Mo.). Fetal bovine serum (FBS) was purchased from GIBCO (New York, USA). All other chemicals were purchased from standard commercial sources. The DU-145 human prostate carcinoma cell line was obtained from the Korean Cell Line Bank, and maintained in DMEM containing phenol red with 10,000 units $/ \mathrm{ml}$ penicillin $\mathrm{G}, 10 \mathrm{mg} / \mathrm{ml}$ streptomycin, and $5 \%$ heat-inactivation FBS in a humidified atmosphere of $95 \%$ air; $5 \% \mathrm{CO}_{2}$ at $37^{\circ} \mathrm{C}$. Culture media were changed every 2 or 3 days. Cells were harvested using trypsin-EDTA and subcultured at weekly intervals.

\section{Measurement of cell viability}

Cell viability was determined by MTT assay. MCF-7 cells were plated at $5 \times 10^{4}$ cells $/ \mathrm{ml}$ in 48 multi-wells in DMEM with $10 \%$ fetal bovine serum and were allowed to adhere overnight. Cells were then treated with each MIF or TAM with the same volume of vehicle $(0.1 \%$ ethanol). For each assay, medium was aspirated from each well and replaced with $400 \mu \mathrm{l}$ of $0.5 \mathrm{mg} / \mathrm{ml}$ MTT in phenol red-free DMEM medium. The treated cells were incubated in a $5 \% \mathrm{CO}_{2}$ incubator at $37^{\circ} \mathrm{C}$ for $4 \mathrm{hr}$. After incubation, the medium was removed and the converted dye was solublized in a 1:1 mixture of DMSO and EtOH. The color intensity was measured by the ELISA Reader (Tecan, Germany) with $570 \mathrm{~nm}$ filter.

\section{$\mathrm{Ca}^{2+}$ mobilization}

Intracellular $\mathrm{Ca}^{2+}$ was measured using Fluo-3/AM. The cells grown in DMEM were washed twice and resuspended in HBSS; $120 \mathrm{mM} \mathrm{NaCl}, 6 \mathrm{mM} \mathrm{KCl}, 1.5 \mathrm{mM} \mathrm{CaCl}, 2 \mathrm{mM}$ $\mathrm{MgCl}_{2}, 10 \mathrm{mM}$ HEPES and $12 \mathrm{mM}$ glucose. For all $\mathrm{Ca}^{2+}$-free 
experiments, $\mathrm{CaCl}_{2}$ - free HBSS with 1mM EGTA was used. For fluo-3/AM loading, $1 \times 10^{6}$ cells were resuspended in HBSS (or $\mathrm{Ca}^{2+}$-free HBSS for $\mathrm{Ca}^{2+}$ starvation) containing 3 $\mu \mathrm{M}$ fluo-3/AM, $0.02 \mu \mathrm{M}$ pluronic F-127. Incubation was performed in the dark at $37^{\circ} \mathrm{C}$ for $25 \mathrm{~min}$. Cells were then washed with HBSS (or $\mathrm{Ca}^{2+}$-free HBSS) and split into 48 well plates at $2 \times 10^{5}$ cells/wells for each treatment. Fluorescent activity was measured (485 $\mathrm{nm}$ excitation/535 nm emission) for $30 \mathrm{~min}$.

\section{Assessment of morphology}

Nuclear condensation and/or chromatin fragmentation found during early apoptosis was determined morphologically by CLSM (LSM510, Carl Zeiss, Oberkohen, Germany) after labeling PI and Hoechst dye. Cells with each treatment were harvested onto a clean, fat-free glass slide with cellspin (Hanil Sci. Industrial, Korea). The cells were then fixed for $30 \mathrm{~min}$ in $4 \%$ paraformaldehyde and then stained in $4 \mu \mathrm{g} / \mathrm{ml}$ Hoechst 33342 or $10 \mu \mathrm{g} / \mathrm{ml}$ PI with $50 \mu \mathrm{g} / \mathrm{ml}$ ribonuclease A for $1 \mathrm{hr}$ at $37^{\circ} \mathrm{C}$. The cells were observed and photographed by CLSM (LSM510).

\section{Cell cycle analysis}

Cells were harvested, fixed with $95 \%$ ethanol for $24 \mathrm{hr}$, incubated with $0.05 \mathrm{mg} / \mathrm{ml}$ PI and $1 \mu \mathrm{g} / \mathrm{ml}$ RNAse A at $37{ }^{\circ} \mathrm{C}$ for $30 \mathrm{~min}$, and analyzed by flowcytometry, using and Epics XL and analysis software (EXPO32TM; Beckman Coulter, MI, USA). The cells belonging to the sub-G1 population were considered to be apoptotic cells; the percentage of each phase of the cell cycle was determined.

\section{Western blot analysis}

Cells were collected by centrifugation at 5,000 rpm for $10 \mathrm{~min}$ at $4^{\circ} \mathrm{C}$. Proteins were extracted by washing cells twice with ice-cold PBS and incubating them for $60 \mathrm{~min}$ on ice in lysis buffer containing $50 \mathrm{mM}$ Tris- $\mathrm{HCl}$ (pH 7.6), $300 \mathrm{mM}$ $\mathrm{NaCl}, 0.5 \%$ Triton X-100, $2 \mathrm{mM}$ phenylmethylsulfonyl fluoride, $2 \mu \mathrm{g} / \mathrm{ml}$ aprotinin, and $2 \mu \mathrm{g} / \mathrm{ml}$ leupeptin. For Western blotting, an aliquot of $60 \mathrm{\mu g}$ of protein was separated by sodium dodecylsulfate-polyacrylamid gel electrophoresis (SDS-PAGE) and then transferred to a nitrocellulose transfer membrane. Blotting was performed using the primary antibodies of anti-Bcl-2, anti-Bax, anti-procaspase-8, anti-cleaved caspase-3, and then with the proper secondary antibody (Sigma, MO, USA). The immuncomplexes were detected by using the enhanced chemiluminescence (ECL) detection kit
(Amersham Pharmacia Biotech Korea, Inc., Seoul, Korea).

\section{Statistical analysis}

All experiments were carried out at least in triplicate. Results were expressed as mean \pm SEM. Statistical significances between the control and the treatment group were determined by one-way analysis of variance and then followed by the Student $\mathrm{T}$ test. In all cases, a $p$ value of less than 0.05 was considered statistically significant.

\section{Results}

\section{Effects of MIF and TAM on cell viability}

When the cells were treated for 2-4 days with 5-25 $\mu \mathrm{M}$ of MIF, the growth and viability of DU-145 cells were significantly decreased in a dose- and time-dependent manner (Fig. 1A). Cell viability was not influenced by 1 day of MIF treatment throughout the concentration range tested (data not shown). However, after 2 days of MIF treatment, cell viability started to decrease. At concentrations greater than $40 \mu \mathrm{M}$ of MIF, cells started to detach from the bottom surface even after 1 day of treatment, and over $70 \%$ of the total cells became detached after 2 days of treatment. Therefore, most

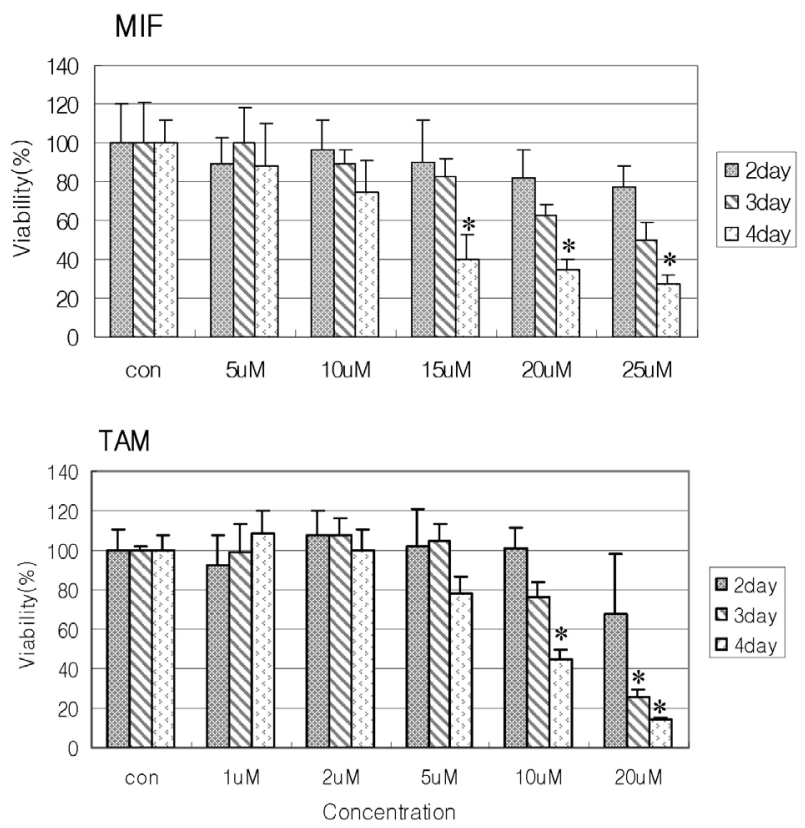

Fig. 1. Effects of MIF and TAM on cell viability in DU-145 prostate cancer cells. Cell viability assay was done by MTT staining method as described in "M\&M". Data are expressed as percent change of the control (con). Data shown are mean of at least three independent experiments, bars, SE. ( ${ }^{*} p<0.05$ vs. control). 
of the ongoing experiments were performed at a concentration of less than $40 \mu \mathrm{M}$ MIF.

Cells treated with $20 \mu \mathrm{M}$ MIF showed $82 \%, 63 \%$, and $34 \%$ of viability on 2,3, and 4 days incubation, respectively, compared to the control.

In the cells treated with TAM, viability was also decreased in a dose- and time-dependent fashion (Fig. 1B). The cytotoxic effect of TAM was stronger than that of MIF in DU-145. Even at $10 \mu \mathrm{M}$, cell viability was decreased severely. Therefore, most of the ongoing experiments were performed at a concentration less than $20 \mu \mathrm{M}$ TAM. However, at a concentration less than $5 \mu \mathrm{M}$, TAM slightly induced cell proliferation. Cells treated with $20 \mu \mathrm{M}$ TAM showed 67\%, $24 \%$, and $17 \%$ viability at 2,3 , and 4 days of incubation, compared to the control.

\section{Assessment of cell morphology}

MIF has been known to induce apoptosis in prostate cancer cells. To examine this in the present experiment, we studied the morphological change in the nuclei of the cells treated by staining with Hoechst and PI dye. The cells were treated with either MIF or TAM, and the morphological change of nuclei was observed by a laser confocal scanning microscope after dye treatments. As shown in Fig. 2, the cells treated with $20 \mu \mathrm{M}$ MIF for 2 days already showed the characteristic nuclei condensation and shrinkage, which was a typical con
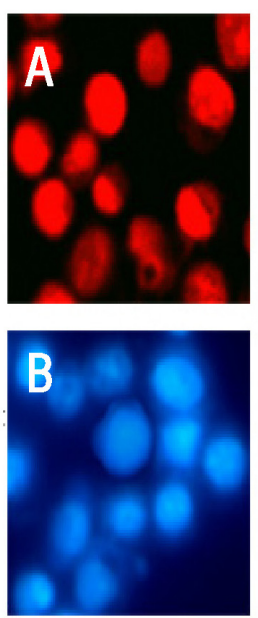

\section{MIF $20 \mu \mathrm{M} \quad$ MIF $40 \mu \mathrm{M}$}
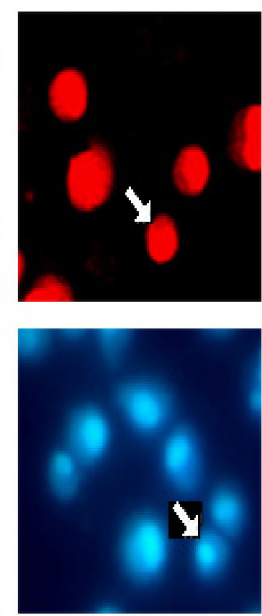
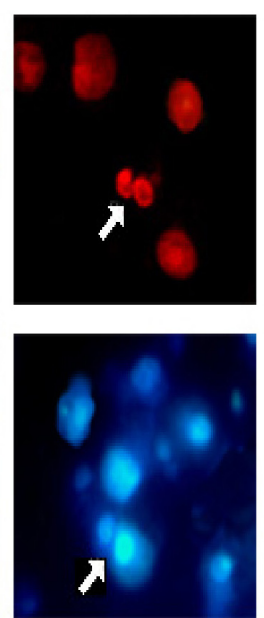

Fig. 2. MIF induces the nuclear changes of apoptosis. DU-145 cells were treated with MIF $(20,40 \mu \mathrm{M})$ for 2 days, then nuclei were imaged under microscopy by PI (A) or Hoechst 33342 (B) staining. Con; nuclei incubated without MIF. Arrows; chromatin condensation or margination of chromatin. early event of apoptotic cell death, in both PI and Hoechst staining. The nuclei in the cells treated with $40 \mu \mathrm{M}$ MIF were severely condensed, and nuclear fragmentation could be found in many cells. In Hoechst staining, condensed and fragmented chromatin were observed as bright spots in the cells treated with $40 \mu \mathrm{M}$ MIF.

TAM has been also known to induce apoptosis in many ER-positive and ER-negative cancer cells. In DU-145 cells treated with 10 or $20 \mu \mathrm{M}$ TAM, severe chromatin condensation and nuclear fragmentation within 2 days of treatment, which was a typical early event of apoptotic cell death, could clearly be found (Fig. 3).

\section{Detection and quantification of apoptosis}

To detect and quantify apoptosis, cells were incubated with MIF and TAM at concentrations of $10 \mu \mathrm{M}$ and $20 \mu \mathrm{M}$, respectively, for 2 days. The results were analyzed by flow cytometer, and the cell population belonging to sub-G1 was considered to be an apoptotic group. As shown in Fig. 4, the cytotoxic effect of TAM was much higher than that of MIF at the same concentrations. Cells treated with $20 \mu$ M MIF showed $9.36 \%$ apoptosis of total cells. However, cells treated with TAM at the same concentration induced $25.31 \%$ apoptosis within 2 days of treatment, which could be a considerable apoptotic percentage compared with the control.

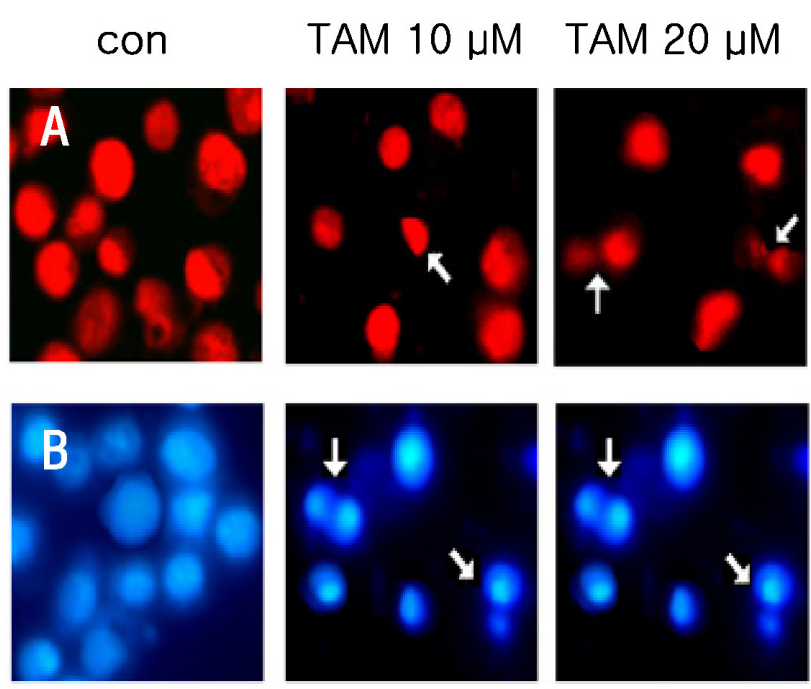

Fig. 3. TAM induces the nuclear changes of apoptosis. DU-145 cells were treated with TAM $(10,20 \mu \mathrm{M})$ for 2 days, then nuclei were imaged under microscopy by PI (A) or Hoechst 33342 (B) staining. Con; nuclei incubated without TAM. Arrows; chromatin condensation or margination of chromatin. 


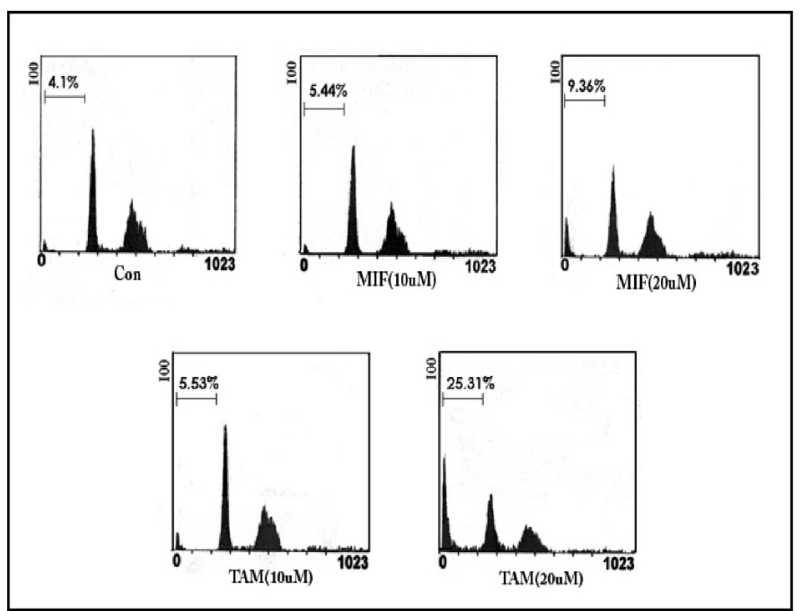

Fig. 4. The identification of apoptosis by sub-G1 analysis in FASC. The percentage in each phase indicates apoptotic population in each treatment. Data shown are from one of three independent experiments.

\section{Effects of MIF and TAM on intracellular $\mathrm{Ca}^{2+}$ levels} $\mathrm{Ca}^{2+}$ homeostasis is very important for many cell functions, including growth, differentiation, and death. In the cells grown at medium containing $1.5 \mathrm{mM} \mathrm{Ca}^{2+}$, the change in intracellular $\mathrm{Ca}^{2+}$ level was examined to find out whether the cytotoxic effect of MIF and TAM was related to intracellular $\mathrm{Ca}^{2+}$ modulation. Both MIF and TAM induced an increase in intracellular $\mathrm{Ca}^{2+}$ level in a dose - and time-dependent manner.

In $40 \mathrm{MIF}$ treatment, the level of intracellular $\mathrm{Ca}^{2+}$ slightly increased up until $25 \mathrm{~min}$ of measurement, compared to the untreated control (Fig. 5A). To check if the $\mathrm{Ca}^{2+}$ concentration level increase was due to $\mathrm{Ca}^{2+}$ influx from the exterior, the same experiment was performed in the EDTA treated $\mathrm{Ca}^{2+}$-free medium. As shown in Fig. 5B, there was no difference in change between the intracellular $\mathrm{Ca}^{2+}$ concentration levels of both the control and the treatment groups. In TAM treated cells, even a $10 \mu \mathrm{M}$ concentration could induce an increase of intracellular $\mathrm{Ca}^{2+}$ level noticeably (Fig. 6A). During the $20 \mu \mathrm{M}$ TAM treatment, the level of intracellular $\mathrm{Ca}^{2+}$ increased continuously until about $18 \mathrm{~min}$ of incubation time and remained a sustained phase after that up to $25 \mathrm{~min}$. When the same experiment was performed in the EDTA treated $\mathrm{Ca}^{2+}$-free medium, no intracellular $\mathrm{Ca}^{2+}$ increase could be found in the TAM treated groups (Fig. $6 \mathrm{~B})$. Therefore, the main source of intracellular $\mathrm{Ca}^{2+}$ increase induced by MIF and TAM treatment was most likely due to the $\mathrm{Ca}^{2+}$ influx from outside the cell.
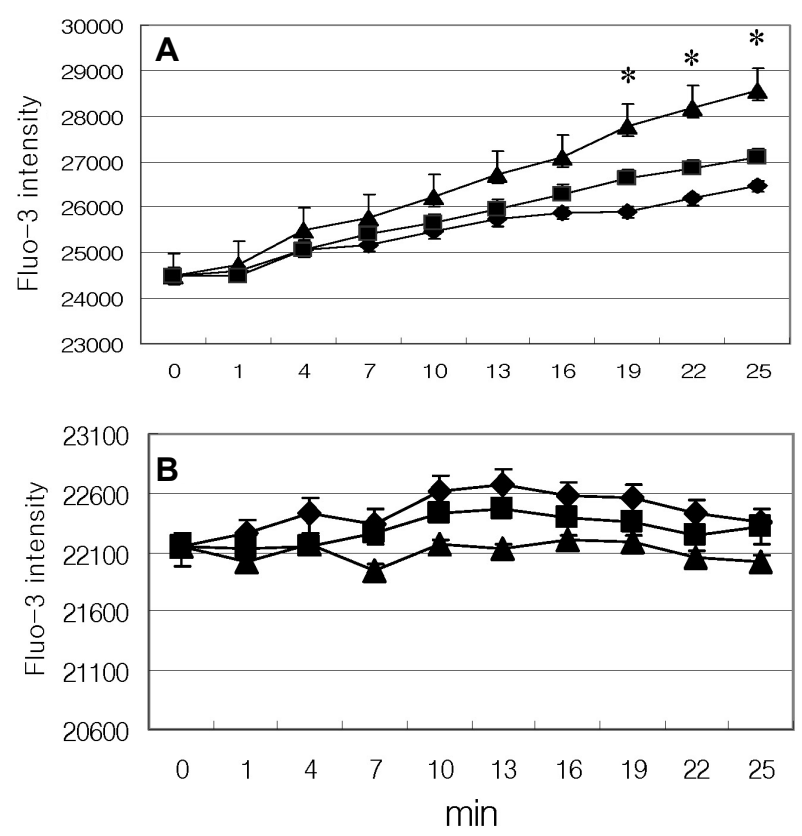

Fig. 5. Effect of MIF on intracellular calcium level in DU-145 cells. For each experiment, $1 \times 10^{6}$ cells were incubated in $1.5 \mathrm{mM}$ calcium-containing buffer (A) or calcium-free buffer (B). Details are mentioned in "M\&M". $\$$ : con, $\mathbf{\square}$ : MIF $20 \mu \mathrm{M}, \mathbf{\Delta}$ : MIF $40 \mu \mathrm{M}$. Data shown are means of three independent experiments, bar, SE. ( ${ }^{*} p<0.05$ vs. control).
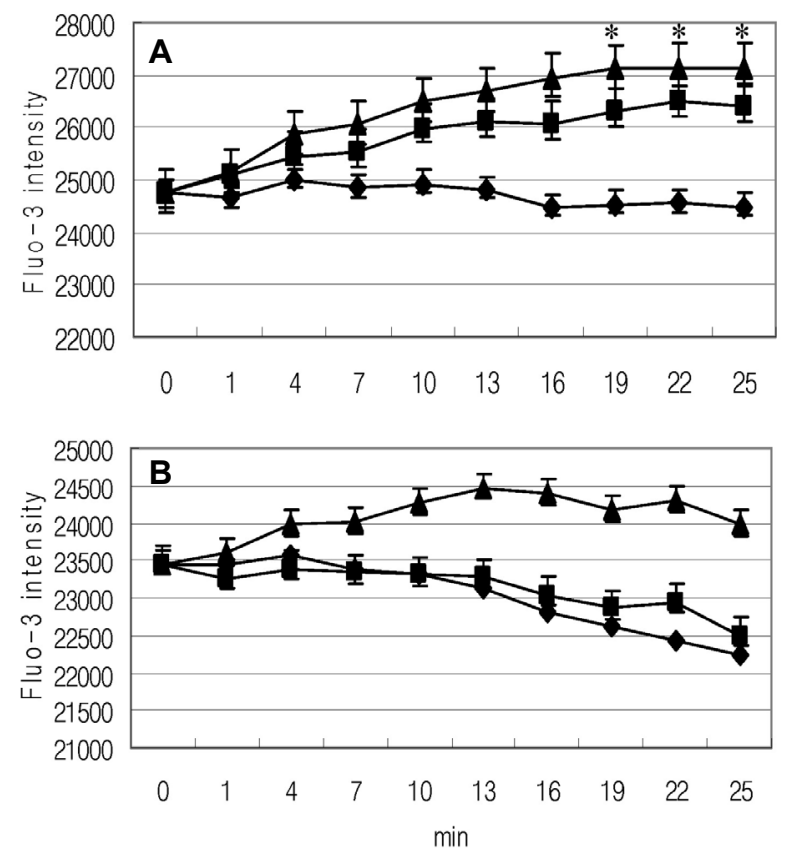

Fig. 6. Effect of TAM on intracellular calcium level in DU-145 cells. For each experiment, $1 \times 10^{6}$ cells were incubated in $1.5 \mathrm{mM}$ calcium-containing buffer (A) or calcium-free buffer (B). Details are mentioned in "M\&M". $\$$ : con, $\mathbf{\square}$ : TAM $10 \mu \mathrm{M}, \mathbf{\Delta}$ : TAM $20 \mu \mathrm{M}$. Data shown are means of three independent experiments, bar, SE. ( ${ }^{*} p<0.05$ vs. control). 


\section{Effects of MIF and TAM on caspase activation and $\mathrm{Bcl}$ family protein expression}

There are two distinct molecular signaling pathways that lead to apoptotic cell death; mitochondria-mediated pathway and receptor-mediated pathway [4]. Procaspase- 8 is cleaved and activated in the early stage of the receptor-mediated pathway. Caspase-3 can be activated in both pathways. The Bcl-2 family proteins are very important in mitochondria-mediated pathways, but the two pathways can also be linked to each other. Therefore, the changes in level of expression of the above proteins were analyzed by Western blotting (Fig. 7). The level of procaspase-8 expression was severely reduced, thus as a result of its cleavage and activation by the $20 \mu \mathrm{M}$ MIF treatment for 2 days. However, the activation of procaspase- 8 was not as prominent in the cells treated for 2 days with $20 \mu \mathrm{M}$ TAM. Activation of caspase-3 showed the opposite results compared to procaspase- 8 . With MIF treatment, caspase- 3 was activated to $164 \%$ of the control, but activated to $267 \%$ in TAM treatment. The level of Bcl-2 expression, an anti-apoptotic protein, decreased noticeably in both treatments. To the contrary, expression of Bax, a pro-apoptotic protein, increased dramatically in both the MIF and TAM treatments.

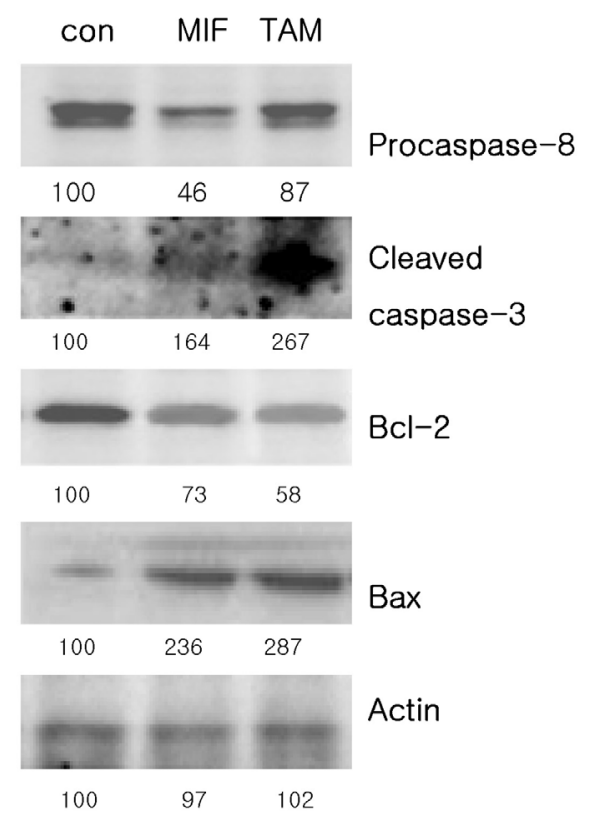

Fig. 7. Western blotting showing the effects of MIF and TAM on caspase activation and $\mathrm{Bcl}$ family protein expression. Cells were treated with $20 \mu \mathrm{M}$ of each MIF or TAM for 2 days. After proteins separation by SDS-PAGE, the proteins were blotted and detected by using ECL detection method. A representative of 3 experiments is shown. (relative densities in number)

\section{Discussion}

Androgen signaling is very important in the development, proliferation, and differentiation of the prostate gland. Androgen bound to the AR translocates to the nucleus to modulate gene expression. The anti-progestin MIF has been known to inhibit the growth of prostate cancer cells [2,12,19]. MIF could induce apoptosis even in AR-negative DU-145 prostate cancer cells, which suggests that the cytotoxicity of MIF is not just based on androgen antagonistic activity. TAM is a well known anti-estrogen drug for the treatment of breast cancer. However, due to its pleiotropic ligand-receptor characteristics, TAM is also used for the treatment of many different types of cancer [17]. Although MIF and TAM have been reported to inhibit the proliferation of AR-negative prostate cancer cells, only a few studies have reported on their mechanisms. In the present study, we report that the cytotoxicity might be initiated by the modulation of intracellular $\mathrm{Ca}^{2+}$ levels. Based on the results of both MTT assay and FACS analysis, TAM exerted a much higher apoptotic activity compared to MIF. Very recently, it was reported that the ER-mediated pathway plays a central role in the growth of normal prostate cells [13]. This finding may support the high cytotoxicity of TAM against DU-145 cells found in the present study. However, since cancerous prostate cells are different from normal cells in many ways, further studies are necessary to determine this. Even though the precise role of MIF and TAM in apoptosis appears to be complex and unclear, it has been known that caspas-3 plays a central role in the terminal execution stage of apoptosis. The activation of caspase- 3 during apoptosis is regulated by multiple pathways; the intrinsic, or mitochondria-mediated pathway, and the extrinsic, or receptor-mediated pathway [4], but the two apoptotic pathways can also be linked through Bcl-2 family proteins. In recent years, a great deal of attention has been placed on the possible correlation between the effects of members of the Bcl-2 family of proteins on $\mathrm{Ca}^{2+}$ mobilization and their role in the control of apoptosis [5]. In the present work, both MIF and TAM induced the increment of intracellular $\mathrm{Ca}^{2+}$ levels in a concentration-dependent manner. Again, TAM showed to have a more prominent effect on the increase of intracellular $\mathrm{Ca}^{2+}$ levels, compared to the effect of MIF. Also the strong apoptotic activity was clearly confirmed in the results of the Western blotting analysis. Both the MIF and TAM treatments over 2 days induced the activation of caspase-3, but the acti- 
vation by TAM was much higher compared to that by MIF. The expression of $\mathrm{Bcl}-2$ protein was noticeably decreased in both MIF and TAM treatment. To the contrary, Bax, a pro-apoptotic protein, increased more than 2-fold in both treatments as expected. The difference in the protein expression levels of procaspase-3 was very interesting. Procaspase- 8 is a cytoplasmic protein. When the death signal reaches to the target cell, it is known to be recruited to the membrane receptor and cleaved to be activated [11]. In our results, MIF induced the procaspase- 8 cleavage very clearly, however, TAM induced just a minor change in the processing of procaspase- 8 . As mentioned above, our results showed more cleaved caspase- 3 in TAM treated cells. These two results are in conflict with one another because it has been reported that death signal induced processing of procaspase- 8 can directly induce the activation of caspase- 3 . To determine the cause of the above contradictory results, the role of other regulatory proteins of apoptosis should be studied further. The regulatory protein, Bid, can be one of the candidates for further study because the two apoptotic pathways are interlinked by the Bid protein in many cases. Another explanation is that MIF and TAM have different upstream pathways in apoptosis. However, those two different pathways are interlinked in the downstream pathway through the modulation of intracellular $\mathrm{Ca}^{2+}$ levels.

In summary, we have provided evidence that MIF and TAM induce an increase in intracellular $\mathrm{Ca}^{2+}$ concentration levels in DU-145 human prostate cancer cells, even though MIF and TAM may induce a different pathway upstream of the apoptotic process. The change in $\mathrm{Ca}^{2+}$ levels leads to apoptotic cell death via caspase-3 activation in the downstream apoptotic pathway.

\section{Acknowledgment}

This work was supported for two years by Pusan National University Research Grant.

\section{References}

1. Bogush, T. A., E. A. Dudko, A. A. Beme, E. A. Bogush, B. E. Polotskiǔ, S. A. Tiuliandin, and M. I. Davydov. 2009. Estrogen receptor expression in tumors different from breast cancer. Antibiot. Khimioter. 54, 41-49.

2. Cabeza, M., E. Bratoeff, I. Heuze, A, Guzmán, G. Gómez, H. Berrios, and A. Rosales. 2007. Antiandrogenic and apoptotic effects of RU-486 on animal prostate. J. Steroid Biochem.
Mol. Biol. 104, 321-325.

3. Couldwell, W. T., D. R. Hinton, S. He, T. C. Chen, I. Sebat, M. H. Weiss, and R. E. Law. 1994. Protein kinase C inhibitors induce apoptosis in human malignant glioma cell lines. FEBS Lett. 345, 43-46.

4. Danial, N. N. and S. J. Korsmeyer. 2004. Cell death: critical control points. Cell 116, 205-219.

5. Demaurex, N. and C. Distelhorst. 2003. Apoptosis-the calcium connection. Science 300, 65-67.

6. El Etreby, M. F., Y. Liang, and R. W. Lewis. 2000. Induction of apoptosis by mifepristone and tamoxifen in human LNCaP prostate cancer cells in culture. The Prostate 43, 31-42.

7. Heerdt, A. S. and P. I. Borgen. 1999. Current status of tamoxifen use;an update for the surgical oncologist. J. Surg. Oncol. 72, 42-49.

8. Kallio, A., A. Zheng, J. Dahllund, K. M. Heishanen, and P. Harkonen. 2005. Role of mitochondria in tamoxifen-induced rapid death of MCF-7 breast cancer cells. Apoptosis 10, 1395-1410.

9. Kroemer, G. and J. C. Reed. 2000. Mitochondrial control of cell death. Nat. Med. 6, 513-519.

10. Moe, B. G., A. B. Vereide, A. Orbo, and G. Sager. 2009. High concentrations of progesterone and mifepristone mutually reinforce cell cycle retardation and induction of apoptosis. Anticancer Res. 29, 1053-1058.

11. Muzio, M, B. R. Stockwell, H. R. Stennicke, G. S. Salvesen, and V. M. Dixit. 1998. An induced proximity model for caspase-8 activation. J. Biol. Chem. 273, 2926-2930.

12. Nishino, T., K. Ishibashi, C, Hirtreiter, and Y. Nishino. 2009. The prostate growth stimulation by progesterone is due to androgenic products and progesterone receptor-mediated mechanisms. Pharmazie. 64, 587-589.

13. Nomura, H., H. Kawashima, S. Masaki, T. Y. Hosono, K. Matsumura, S. Tamada, T. Tanaka, and T. Nakatani. 2009. Effect of selective estrogen receptor modulators on cell proliferation and estrogen receptor activities in normal human prostate stromal and epithelial cells. Prostate Cancer Prostatic Dis. 12, 375-381.

14. Ozaki, M. A., H. Matsubara, T. Sato, K. Ikuta, Y. Nishizawa, and K. Suzumori. 2005. Role of apoptosis controlled by cytochrome c released from mitochondria for luteal function in human granulose cells. Am. J. Reprod. Immunol. 53, 144-152.

15. Schendel, S. L., Z. Xie, M. O. Montal, S. Mastumyama, M. Montal, and J. C. Reed. 1997. Channel formation by antiapoptotic protein Bcl-2. Prog. Biophys. Mol. Biol. 64, 5113-5118.

16. Sharma, A. K. and B. Rohrer. 2004. Calcium-induced calpain mediates apoptosis via caspase-3 in a mouse photpreceptor cell line. J. Biol. Chem. 279, 35564-35572.

17. Singh, M. N., P. L. Martin-Hirsch, and F. L. Martin. 2008. The multiple applications of tamoxifen: an example pointing to SERM modulation being the aspirin of the 21st century. Med. Sci. Monit. 14, 144-148.

18. Smaili, S. S., Y. T. Hsu, A. C. P. Carvalho, T. R. Rosenstock, J. C. Sharpe, and R. J. Youle. 2003. Mitochondria, calcium and pro-apoptotic proteins as mediators in cell death 
signaling. Braz. J. Med. Biol. Res. 36, 183-190.

19. Spit, I. M. and C.W. Bardin. 1993. Mifepristone (RU-486) a modulator of progestin and glucocorticoid action, N. Engl. J. Med. 329, 404-412.

20. Taplin, M. E., J. Manola, W. K. Oh, P. W. Kantoff, G. L. Bubley, M. Smith, D. Barb, C. Mantzoros, D. P. Gelmann, and S. P. Balk. 2008. A phase II study of mifepristone (RU-486) in castration-resistnat prostate cancer, with a correlative assessment of androgen-related hormones. J. Compilation 101, 1084-1089.

21. Zhang, W., L. Huang, Y. Zhuang, and W. Wang. 2008. The effect of mifepristone on apoptosis and caspase-3 activation in human ovarian luteinized granulose cells. Eur. J. Obstet. Gynecol. Reprod. Biol. 141, 131-136.

22. Zhang, H., J. J. Lu, Q. Z. Gao, and J. Zhang. 2006. Induction of apoptosis by mifepristone in androgen-independent prostate cancer cell lines in vitro. Zhonghua Wai Ke Za Zhi 44, 382-385

23. Zheng, A., A. Kallio, and P. Harkonen. 2007. Tamoxifen-induced rapid death of MCF-7 breast cancer cells is mediated via ERK signaling and can be abrogated by estrogen. Endocrinol. 148, 2764-2777.

\section{초록 : DU-145 전립선 암세포에 있어서 mifepristone과 tamoxifen이 칼슘조절에 미치는 영향}

\section{김여름 · 김병기*}

(부산대학교 생명과학과)

Mifepristone (MIF)와 Tamoxifen (TAM)은 각각 전립선암과 유방암치료제로 오랫동안 사용되고 있다. MIF는 안드로겐수용체(AR) 양성인 세포와 음성이 세포 모두에서 세포사멸을 유도하며, TAM 은, 리간드-수용체작용 기 작의 다양한 특성에 의하여 에스트로겐(ER) 양성인 세포뿐 만 아니라 다른 종류의 암세포에서도 세포사멸을 유 도하는 것으로 알려져 있다. 본 연구에서는 AR 음성인 DU-145 전립선암세포에 있어서, MIF와 TAM의 세포독성 이 세포 내 칼슘농도 변화에 기인된 세포사멸기작에 의한 것임을 보여준다. MIF와 TAM을 처리시 세포성장은 농도와 시간의존적으로 감소하였으며, confocal laser scanning microscopy (CLSM)과 fluorescence-activated cell sorting (FASC)로 세포를 분석한 결과 각각 $\mathrm{MIF}$ 와 $\mathrm{TAM}$ 을 2일간 처리한 세포에서 세포사멸이 진행되는 것을 관찰하였다. 세포독성효과를 비교했을 경우, TAM이 MIF 보다 강하게 작용하였다. MIF와 TAM을 처리한 세포 내 칼슘변화 측정 시, 칼슘농도 또한 처리 약물의 농도와 시간 의존적으로 증가하였다. $1.5 \mathrm{mM}$ 칼슘배지와 칼슘 제거된 배지에서의 실험결과를 비교한 바, 세포 내 칼슘증가는 외부로부터의 유입에 의한 것으로 생각된다. 세포 독성효과와 마찬가지로 칼슘증대 효과 역시 TAM에서 뚜렷하게 나타났다. 수용체 매개 세포사멸기작의 초기에 관여하는 procaspase-8은 MIF 처리 시 뚜렷이 활성화 되었으나, TAM의 경우 활성화가 MIF의 경우에 비해 강하 지 못하였다. 그러나, 세포사멸의 중추적인 역할을 하는 caspase-3은 TAM 을 처리한 세포에 있어서 활성 정도가 훨씬 높았다. 세포사멸과정의 중요한 조절 단백질인 Bcl-2 그룹단백질의 발현을 조사해 본 결과, 세포사멸 억제단 백질인 Bcl-2의 발현은 MIF, TAM 처리 시 동일하게 감소한 반면, 촉진단백질인 Bax의 발현은 2-3배 가량 증대 되었다. 이상의 결과로 보아 MIF와 TAM은 세포 내 칼슘조절을 통하여 세포사멸을 유도하나, 세포사멸의 초기단 계는 $\mathrm{MIF}$ 와 $\mathrm{TAM}$ 이 서로 다른 경로를 경유할 가능성이 있는 것으로 생각된다. 